\title{
Constructivism and Learner Autonomy in Foreign Language Teaching and Learning: To what Extent does Theory Inform Practice?
}

\author{
Ping Wang \\ School of Foreign Languages, Jiaxing University, Zhejiang, China \\ Email: pwang886@hotmail.com
}

\begin{abstract}
Teachers' definition of what knowledge is, how people acquire it, and how we determine whether knowledge has been acquired or not influence greatly how we understand the teacher's role in the classroom and to what extent we promote learner autonomy in the classroom. Learner-centeredness is one of the most important principles of constructivist FLT. Thus, we could say to a great extent constructivism in education informs the promoting of learner autonomy in the language teaching and learning today.
\end{abstract}

Index Terms - constructivism, learner autonomy, extent, inform

\section{INTRODUCTION}

Like the proverbial horse led to water but which must do the drinking itself, even with the best teachers and methods, students are the only ones who can actually do the learning. As Nyikos and Oxford (1993: p.11) put it: "learning begins with the learner". However it takes me many years to truly understand this as a language teacher.

I have studied English as a foreign language since 1978. My English teachers in China were using a mixture of the grammar-translation method and the audio lingual method. Most of my classmates couldn't communicate in English but some of them develop very good reading and writing competence in English. When graduated from a teacher's college, I started to work as an English teacher in 1982. The communicative language teaching movement started in the area where I was working 10 years later. We finally threw away the text books which I used ten years ago as a student, and had new task-based text books. No matter what method the teachers use, I noticed that there were always some learners more successful than the rest in the same classroom using the same materials with the same teacher. What makes some students better language learners?

I found that one group of Year 8 girls of my mandarin lesson became very noisy, and I was thinking of a new seating plan when a girl asked me whether it was possible they did the seating plan for me. To be honest, I was hesitant. But the girl said she thought friends learnt better when they sat together and "you can rearrange it if it doesn't work." So I agreed and it worked perfectly until now. The first time when every girl was seated, the girl who made the seating plan stood up and gave a short speech to her peers saying that they should all appreciate the opportunity to sit next to their friends in Mandarin lesson, therefore they should not take advantage of it by talking instead of studying, otherwise they would have to sit where the teacher ordered them to. I dare say that was one of the best Chinese Mandarin lessons I have had since I came to the UK. They were so cooperative and the atmosphere in the classroom had never been so good. What is behind the magical change?

Better language learners are not necessarily more intelligent but they are more or less more autonomous if we observe carefully how they learn languages. The same group of students behaved so differently just because I had learned to let go, and they had taken hold once. According to Kumaravadivelu (2003: p.131), in a rapidly changing world where instant and informed decision making is a prerequisite for successful functioning, helping learners become autonomous is one way of maximizing their chances for success. Considering the importance of learner autonomy, I would try to find out what ordinary teachers can do to promote learner autonomy in the language classroom. I will begin by looking at the basic theory behind the learner autonomy which is constructivism in education, I will then discuss definition and classification of learner autonomy, and go on from there to look at it from a theoretical perspective and rethink my own practice of promoting learner autonomy in my teaching practice. At the same time I will examine how Constructivist teaching and learning led by constructivism encourage learner autonomy. Later I would consider the problems we might encounter when promote leaner autonomy.

\section{WHAT IS CONSTRUCTIVISM?}

Constructivism is not a new concept. It has its roots in philosophy and has been applied to sociology and anthropology, as well as cognitive psychology and education. The first constructivist philosopher may be Giambatista Vico who commented in a treatise in 1710 that "one only knows something if one can explain it" (Yager, 1991). But the first major contemporaries to develop a clear idea of constructivism as applied to classrooms and childhood 
development were Jean Piaget and John Dewey (1966). Piaget's constructivism is based on his view of the psychological development of children. In a short summation of his educational thoughts, Piaget (1973) called for teachers to understand the steps in the development of the child's mind. The fundamental basis of learning, he believed, was discovery: "To understand is to discover, or reconstruct by rediscovery, and such conditions must be complied with if in the future individuals are to be formed who are capable of production and creativity and not simply repetition."

The Russian Lev. S Vygotsky is also important to constructivism although some commentators believe that Vygotsky is not a constructivist because of his emphasis on the social context in learning, but others see his stress on children creating their own concepts as constructivist to the core. Vygotsky considered an individual's cognitive system to be a direct result of and inseparable from social life (Vygotsky, 1987).

According to Audrey Gray (1997), constructivism is a view of learning based on the belief that knowledge isn't a thing that can be simply given by the teacher at the front of the room to students in their desks. Rather, knowledge is constructed by learners through an active, mental process of development; learners are the builders and creators of meaning and knowledge. So a constructivist classroom should be learner-centered, and the teacher provides students with experiences that allow them to hypothesize, predict, manipulate objects, pose questions, research, investigate, imagine, and invent. The teacher's role is to facilitate this process.

Similar to this Duffy \& Jonassen (1992) claims that Constructivists believe that knowledge and truth are constructed by the learner and do not exist outside of his mind. Therefore, according to constructivists, learners construct their own knowledge by actively participating in the learning process. Constructivist instructional developers value collaboration, learner autonomy, generativity, reflectivity and active engagement.

Review the main principles of constructivism in the context of education, we could say that constructivism emphasises learning and not teaching, encourages learner autonomy and personal involvement in learning. Numerous researchers, educators and authors are actively engaged in using constructivist principles to design and implement new learning environments showing that theory can effectively guide educational practice.

\section{DEFINITION AND CLASSIFICATION OF LEARNER AUTONOMY}

Holec defines learner autonomy as: 'the ability to take charge of one's own learning', which he then specifies as 'to have, and to hold, the responsibility for all the decisions concerning all aspects of this learning,' (1981: p.3). Trebbi argues (1996: p.290) that 'taking charge of one's own learning' is a tautology as no learning takes place unless the learner is in charge; it is a prerequisite of learning.

Many researchers like Dikenson and Wenden (1995); Pemberton et al. (1996); Benson and Voller (1997) are involved into the topic of autonomy in Language learning. Littlewood (1999:71) summerise the central features of their opinions as follow: Students should take responsibility for their own learning. This is both because all learning can in any case only be carried out by the students themselves and also because they need to develop the ability to continue learning after the end of their formal education. 'Taking responsibility' involves learners in taking ownership ( partial or total ) of many processes which have traditionally belonged to the teacher, such as deciding on learning objectives, selecting learning methods and evaluating progress.

Kumaravadivelu(2003:p.p.133;141) thinks there are two complementary views on learner autonomy, particular with regard to its aims and objectives. He calls them a narrow view and a broad view of learner autonomy. The narrow view of learner autonomy involves, simply, enabling learners to learn how to learn. He explains that this enabling process includes equipping them with the tools necessary to learn on their own, and training them to use appropriate strategies for realizing their learning objectives. Like Benson and Voller (1997: p.2), he believes that the broad view treats learning to learn a language as a means to an end, the end being learning to liberate. Therefore he took a step further by naming the narrow one as academic autonomy which enables learners to be strategic practitioners in order to realize their learning potential, and the broad view one as liberatory autonomy which empowers learners to be critical thinkers in order to realize their human potential.

The idea of the broad view of autonomy has been posed by many educational philosophers such as Paulo Freire (1970), by social scientists such as Ivan Illich (1971), by general educationists such as Henry Giroux (1988) and Roger Simon (1987) and other scholars such as Phil Benson (1997,2001) and Alastair Pennycook (1997) in the L2 field share the similar idea also. While these scholars tell us what learner autonomy actually is, according to Kumaravadivelu (2003) they also tell us what it is not: Autonomy is not independence, that is, learners have to learn to work cooperatively with their teachers, peers, and the educational system; Autonomy is not context-free, that is, the extent to which it can be practiced depends on factors such as learners' personality and motivation, their language learning needs and wants, and the educational environment within which learning take place; and Autonomy is not a steady state achieved by learners, that is, autonomous learners are likely to be autonomous in one situation, but not necessarily in another, and they may well very well choose to look for teacher direction at certain stages in their learning.

Now we could say that underlying the concept of learner autonomy is constructivist psychological theory. We try to make sense of the world around us based on our previous experience and pre-knowledge. According to Kelly (1953: p.50) we anticipate events by 'construing their replications', In other words we interpret them so that they assume meaning. In themselves they carry no meaning: meaning is applied by the individual who interprets. We differ from each other in the way we construct events and we have different approaches to our anticipation of the same events (1953: 
p.55). Thus learning processes are individual, based on the learner's pre-knowledge and can only be monitored by the learner himself. In classroom terms this means that each learner will encounter the foreign language and the material through which he is expected to learn the language in an individual way, which varies from one learner to the other. That is why the focus has to be on the individual learner and on his needs in the learning process.

\section{Promoting Learner Autonomy in Second Language Classroom}

If autonomous learners are more successful language learner, what can a teacher do to promote learner autonomy in a second language classroom?

Stern (1975) believed that the good language learner is characterised by a personal learning style or positive learning strategies. As a result, for encouraging learners to improve their learning processes and products it is important that teachers and lecturers recognize the learning styles and strategies of their learners. When teach Chinese, I found the students depend on too much on Pinyin and reluctant to focus on the Chinese characters. So I make flash cards of characters and play the game: Listen and Touch. I read the character, two students stand near the characters. The first who touch the character win the game. I thought it might be very popular and fun. But the truth is that some students enjoy it very much while others especially those who are a little bit shy don't want to participate at all. The same situation happened when we do another game like Listen and draw. Although most students like the game, however there are always some students complaining that they can't draw at all. I realised there is not a size suit for all. Each student has his/ her own learning style. Tactile Learners might enjoy drawing and board games but not auditory learners. Visual Learners might like the posters and pictures you choose but kinesthetic learners probably not. Analytic Learners perhaps prefer to be taught the rule of grammars but how about global learners who do not like to be bored. Information needs to be presented in an interesting manner using attractive materials. However it is not enough only we teachers notice different student has different learning style. It is much more important to let the students know about their own learning style if they are to take responsibility of their learning process.

We can find many different theories of learning strategies. One very useful theory has been developed by Oxford (1990). She has divided the strategies into two main classes: direct and indirect ones. Direct strategies are those that directly involve the target language. They are composed of memory strategies for remembering and retrieving new information, cognitive strategies for understanding and producing the language. Indirect strategies are those that support and manage language learning without directly involving the target language. They are composed of meta-cognitive strategies for coordinating the learning process, affective strategies for regulating emotions and attitudes, and social strategies for learning and working with others. These research provided us with useful insights into how different students will approach language learning differently and therefore it is important for language teachers to help them to understand what the general learning strategies are and more importantly, to identify the strategies which suit their learning objectives and their personality traits best. Gail Ellis and Barbara Sinclair (1989) and Anita Wenden (1991) offer useful suggestion for teachers on this task. They think it would be useful if we, as language teachers, encourage discussion in the classroom about language and language learning; help learners become aware of the wide range of alternative strategies available to them for language learning; create a learning environment where learners feel they can experiment with their language learning, counsel and give guidance to individual learners when possible and negotiate with learners about course content and methodology if appropriate. From my own teaching experience and my observation of my colleagues', I find most of these suggestions useful and reasonable. However, I found it hard to negotiate with learners about course content in secondary schools especially with learners younger than 15 no matter in China or the UK. First, we have to face the reality that students have limited knowledge about the language and language learning as well. For example, if we do ask students to choose the topic they like, it is very likely that they will choose according to their mood and taste. And different students have different opinions. There are normally about 50 students in one class in China and around 30 in the UK. I admit that it is not realistic to negotiate this with the students during the class time and it is also meaningless in my eyes. Involve learners into the learning process doesn't mean that learners don't need the guide of the teachers although I do agree that negotiation unites teachers and students in a common purpose.

In a recent summary of learner autonomy in language education, Benson (2001) distinguishes five different types of practice to foster autonomy: Resource-based approaches, which emphasize independent interaction with learning Materials(e.g. indiviaualised learning or peer teaching); Technology-based approaches, which emphasize independent interaction with educational technologies (e.g. computers); Learner-based approaches, which emphasize the direct production of behavioural and psychological changes in the learner (e.g. various forms of leaning strategy training); Classroom based approaches, which emphasize changes in the relationship between learners and teachers in the classroom and learner control over the planning and evaluation of learning; Curriculum-based approaches, which extend the idea of control over the planning and the evaluation of learning to the curriculum as a whole.

As a language teacher, I have used the first four approaches to promoting leaner autonomy in my classroom. When in China, I have tried the learner-based approaches and the classroom based approaches because I noticed many of my students who failed to learn English well due to the fact that they don't know how to learn it effectively. What I have done was designing a questionnaire aiming for help them identify their own language leaning style and their learning strategies. And I would introduce the knowledge of general learning style and strategies to make sure every student 
know how people should learn languages. Later I would talk to them individually to help each student analysis the problems of the strategies they use and what strategies might be more suitable for him/ her according to her/his own learning style and habit as well. In fact, students learn much more effectively after they have been trained to learn "how to learn" and as for the Classroom-based approach, I tried to ask my pupils to design the end of term test themselves. I assessed them by the quality of their paper. In this way, I found them much more motivated. Because normally they just sit there waiting to be tested but now they have the control of test. Resource-based approaches and Technology-based approaches proved very useful in my mandarin lessons in the UK. Peer teaching are sometimes much more effective than you stand in front struggling to catch the students' attention who are already bored. And it also offers opportunity for talented students to "show off" a bit in front of their peers which is a resource of motivation, too. Students rarely get bored in the computer room because there they are in control of the topic and the pace of learning. And they are not afraid of making mistakes there. With some well designed program like Euro-talk Chinese beginners, you have choices over easy game and hard game after practice. But in the long-term goal, I think Curriculum-based approaches should play a very important role in the process of promoting learner autonomy. Many researchers who see education from the constructivist' point of view share the same opinion.

Negotiation is an important aspect of a constructivist classroom. It unites teachers and students in a common purpose. Smith (1993) confirms that negotiating curriculum means "custom-building classes every day to fit the individuals who attend" (p. 1). Boomer (1992: p.14) explains that it is important when negotiating for teachers to talk openly about how new information may be learned and about constraints such as obligatory curriculum. Cook (1992: p.16) explains why negotiating the curriculum with students is important: Learners will work harder and better, and what they learn will mean more to them if they are discovering their own ideas, asking their own questions, and fighting hard to answer them for themselves. They must be educational decision makers. Out of negotiation comes a sense of ownership in learners for the work they are to do, and therefore a commitment to it. The basic philosophy of Benson's five approaches of fostering autonomy in the language classroom is: learner-centered. While a Constructivist Classroom is a 'Student-Centered' Classroom. According to Audrey Gray (1997) Constructivist classrooms are structured so that learners are immersed in experiences within which they may engage in meaning-making inquiry, action, imagination, invention, interaction, hypothesizing and personal reflection. Teachers need to recognize how people use their own experiences, prior knowledge and perceptions, as well as their physical and interpersonal environments to construct knowledge and meaning. The goal is to produce a new learning environment that provides meaningful learning experiences for autonomous learners. Back to the question at the beginning, what can a language teacher do to promote learner autonomy in the classroom? .... Thinks it is crucial to 'increase learner involvement in organizing the learning process' which means share responsibility with the learners about their learning process and 'a change in the teacher's role' which means the teacher dose not consider the students empty vessels that need to be filled with words of wisdom coming from the teacher and the course book- but views him/herself as a helper and instructional designer who leads learner to discover and create their own meanings about the world.

\section{THE Risk OF Promoting LEARNER AUTONOMY}

The raising of learner autonomy is not always pure joy and fun. It involves risks. Some conflicts among the students or between you and the students may -and almost inevitably will- develop. As Dam (1995) summaries the problems you may encounter:

It might be difficult to bring learners to make decisions and accept responsibility for these decisions. And it might not be easy to respect the students' right to make 'wrong' decisions... You may not find enough ready-made activities in the course book that are suitable for autonomous learning and have to spend some time designing new ones... It may be and in fact it is scary to relinquish the traditional means of classroom control and rely on new or modified methods of discipline. In general, it might be difficult for you to 'let go' and trust the pupils' ability to 'take hold'.(the y8 student example) On the other hand, required course content and externally applied assessments are realities that teachers must accommodate. Thus it is very likely that sometimes we may panic and believe everything was a mistake. We might fell angry and blame the students for not appreciating the wonderful opportunity they have been offered. As a result, we might go back to traditional teacher-centered classroom to get control. However, if we always bear in mind that 'learning begins with the learner', we may calm down and do our job more patiently and in the end more effectively.

\section{CONCLUSION}

I believe a teacher's job is watching, listening, and asking questions of students in order to learn about them and about how they learn so that we may be more helpful to them. Lester and Onore (1990) claims that a teacher's beliefs about teaching and learning affect his/her classroom practice, as well as his/her ability to change his/her practice. Especially, teachers' definition of what knowledge is, how people acquire it, and how we determine whether knowledge has been acquired or not influence greatly how we understand the teacher's role in the classroom and to what extent we promote learner autonomy in the classroom. Learner-centeredness is one of the most important principles of constructivist FLT. According to Marcus Reinfried (2000) the content of learner-centeredness is individualization 
learning and autonomy of learner. Thus, we could say to a great extent constructivism in education informs the promoting of learner autonomy in the language teaching and learning today.

\section{REFERENCES}

[1] Applebee, A.N. (1993). Literature in the secondary school: Studies of curriculum and instruction in the United States. Urbana, Il: National Council of Teachers of English.

[2] Audrey Gray. (1997). Contructivist Teaching and Learning SSTA Research Centre Report \#97-07.

[3] Benson, P. and P. Voller. (eds) (1997). Autonomy and Independence in language learning. London: Longman.

[4] Benson, P. (2001). Teaching and Researching Autonomy in Language Learning. Harlow: Lonman.

[5] B. Kumaravadivelu. (2003). Beyond Methods: Macrostrategies for language teaching. New Haven and London: Yale University Press.

[6] Boomer, G. (1992). Negotiating the curriculum. In G.g Boomer, N. Lester, C. Onore, \& J. Cook (Eds.), (1992). Negotiating the curriculum: Educating for the 21st century (pp. 4-14). London: The Falmer Press.

[7] Carr, C., Jonassen D.H. \& Yueh, H. (1998). Computers as mind tools for engaging learners in critical thinking. Education Abstracts, 18, 150.

[8] Cook, J. (1992). Negotiating the curriculum: Programming for learning. In G. Boomer, N. Lester, C. Onore, \& J. Cook. (Eds.), (1992), Negotiating the curriculum: Educating for the 21st century (pp. 15-31). London: The Falmer Press.

[9] Dam, L. (1995). Learner Autonomy 3: From theory to Practice. Dublin: Authentik.

[10] Dewey, J. (1916). Democracy and Education. New York: The Free Press.

[11] Dickinson, L. and A. Wenden(eds.) (1995). Autonomy, self-direction and self access in language teaching and learning. special issue of system 23/2.

[12] Duffy, T. M. \& Jonassen, D. H. (1992). Constructivist and the technology of instruction: A conversation, Hillsdale, NJ: Lawrence Erlbaum Associates.

[13] Freire, P. (1972). Pedagogy of the oppressed. Harmondsworth, United Kingdom: Penguin Books.

[14] Holec, H. (1981). Autonomy and Foreign Language Learning. Oxford: Pergamon.

[15] Ingvarson, L. \& McDonald, H. (1997). Technology: a catalyst for educational change. Education Abstracts, 17, 267.

[16] Illich, I. (1970). Deschooling Society. Harmondsworth, United Kingdom: Penguin Books.

[17] Kelly, G. (1963). A Theory of Personality. New York: W. W. Norton \& Company.

[18] Lester, N.B. \& Onore, C.S. (1990). Learning Change: One school district meets language across the curriculum. Portsmith, NH: Boynton/Cook Publishers.

[19] Littlewood.W. (1999). Defining and developing autonomy in East Asian contexts. Applied Linguistics 20/1.Oxford University press.

[20] Marcus Reinfried. (2000). Can Radical Constructivism Achieve a Viable Basis for Foreign Language Teaching?- A Refutation of the 'Wolff-Wendt' Theorem.

[21] Marcus, S. (1995). E-meliorating student writing. Electronic Learning, 14, 18-19.

[22] Oxford, R (1990). Language Learning Strategies: What Every Teacher Should Know. New York: Newbury House/Harper and Row.

[23] Pemberton, R, E.S.L, Li, W.W.F. Or and H.D. Pierson. (eds) Taking control: Autonomy in language learning. Hong Kong: Hong Kong University Press.

[24] Pennycook, A. (1997). Cultural alternatives and autonomy. in P. Benson and P. Voller (eds.). Autonomy and independence in language learning. London: Longman, pp.35-53.

[25] Portier, S. J. \& Wagemas, L. J. J. M. (1995). The assessment of prior knowledge profiles: A support for independent learning? Distance Education, 16(1), 65-87.

[26] Piaget, Jean. (1973).To Understand is to Invent. New York: Grossman.

[27] Schwen, T.M., Kalman, H. K., Hara, N., \& Kisling, E. L. (1998). Potential knowledge management contributions to human performance technology research and practice. Educational Technology Research and Development, 46(4), 73-89.

[28] Smith, K. (1993). Becoming the "guide" on the side. Educational Leadership, 51(2), 35- 37.

[29] Trebbi, T. (1996). Apprentisage auto-dirige et enseignement secondaire: un centre de ressource au college. Melanges Pedagogiques Crapelle 22. Universite Nancy 2.

[30] Vygotsky, L.S. (1987). Collected works. R.W. Rieber \& A.S. Carton (eds.), N. Minick (trans.). New York: Plenum.

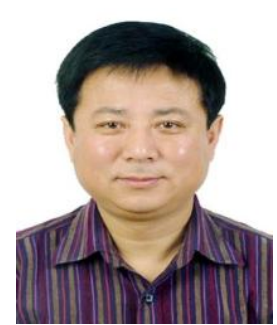

Ping Wang has a B.A. from English Department II, Shanghai International Studies University. He had an M.A. with Merit in International English Language Teaching and Applied Language Studies from London Metropolitan University. He has been an associate professor in the College of Foreign Languages at Jiaxing University since 2007. He was teaching Mandarin Chinese in schools in Central London, which was interviewed and reported by BBC on November 24, 2006 (http://news.bbc.co.uk/2/hi/school_report/6182526.stm). He was awarded the Confucius Institute Chinese Director by the Confucius Institute Headquarters on September 1st, 2009. His research field is on both TEFL and TCFL. Lots of his papers have been issued, among which two are in SSCI (Social Science Citation Index). 